\title{
Colombia sees fourfold increase in microcephaly cases in a year
}

\section{Claudia Collucci}

Sao Paolo

The number of babies born with microcephaly in Colombia increased fourfold between 2015 and 2016, coinciding with a widespread outbreak of Zika virus in the country, a report from the US Centers for Disease Control and Prevention (CDC) and the Colombian health department has shown. ${ }^{1}$

There were 476 cases of microcephaly recorded in Colombia between March and November this year, compared with 110 cases in the same period in 2015, showing an increase in prevalence from 2.1 cases for every 10000 live births to 9.6 cases per 10000

At its peak in July, microcephaly cases in Colombia were nine times higher than in the same month in 2015, the report said.

Of all the microcephaly cases seen in 2016, about a third (147) had laboratory evidence of Zika infection and $4 \%$ had evidence of other infections that can cause microcephaly, such as toxoplasmosis, herpes, cytomegalovirus, or syphilis. Other fetuses were not tested or their microcephaly had no clear cause.

The peak in cases came around six months after the period in which the highest number of new Zika infections was reported, which suggests that the highest risk period for Zika associated microcephaly is likely to be in the first half of pregnancy, the CDC said.

"This finding confirms that countries with Zika virus outbreaks are likely to experience large increases in microcephaly and other Zika related birth defects," the CDC said.

Colombia has had the second largest Zika epidemic after Brazil, where Zika arrived in May 2015. ${ }^{2}$

The latest report on Zika from the World Health Organization showed that 29 countries had reported a total of 2436 microcephaly cases, 2211 of them in Brazil. The Colombian government has reported only 60 cases to $\mathrm{WHO}^{3}$

Martha Ospina Martinez, director general of Colombian's National Health Institute, said that there was no discrepency between the WHO and CDC figures.
"Up to [the WHO] report only 60 babies with microcephaly had had a confirmation of Zika virus infection as the only reason that would explain microcephaly. All other cases are either discarded or under investigation," said Martinez.

Researchers have suggested several possible reasons for the different rates of microcephaly in Colombia and Brazil-including the fact that most Colombians live at altitudes above 2000 metres, where Zika carrying mosquitoes are not active.

Another possible reason could be that women were advised in February to consider delaying pregnancy for six months. Between 2015 and 2016 the number of live births in Colombia fell by about 18000 .

Several experts also have suggested that women in Colombia also took advantage of more permissive abortion laws, an option that was not available to women in Brazil, where the abortion law is highly prohibitive.

Since February, CDC and the Colombian ministry of health have been collaborating on the "Enhanced Surveillance Project of Pregnant Women with Zika" in the three cities with the highest incidence of the virus in pregnant women.

The project will give more accurate estimates of the risk for microcephaly and other adverse birth outcomes among fetuses and infants of mothers with Zika virus disease during pregnancy.

1 Cuevas EL, Tong VT, Rozo N. Preliminary report of microcephaly potentially associated with Zika virus infection during pregnancy: Colombia, January-November 2016. www.cdc. $\mathrm{gov} / \mathrm{mmwr} / \mathrm{volumes} / 65 / \mathrm{wr} / \mathrm{mm} 6549 \mathrm{e} 1 . \mathrm{htm}$.

2 Dyer O. Zika virus spreads across Americas as concerns mount over birth defects. BMJ 2015;351:h6983 doi:10.1136/bmj.h6983 pmid:26698165.

3 WHO. Situation report: Zika virus, microcephaly, Guillain-Barré syndrome. 2016. apps. who.int/iris/bitstream/10665/251905/1/zikasitrep8Dec2016-eng.pdf?ua=1.

Published by the BMJ Publishing Group Limited. For permission to use (where not already granted under a licence) please go to http://group.bmj.com/group/rights-licensing/ permissions 